\title{
DISAMANTLING OF THE SPITZENKANDIDATEN MECHANISM AFTER THE 2019 EUROPEAN ELECTIONS - FAILURE OF EU DEMOCRACY OR POLITICAL PRAGMATISM?
}

\author{
Anna WIERZCHOWSKA, PhD \\ University of Economics and Human Sciences in Warsaw, Poland \\ a.wierzchowska@,vizja.pl
}

\begin{abstract}
The introduction of a new method of electing the President of the European Commission in 2014, based on a specific interpretation of art. 17 of the TEU, has become a crucial event in the political life of the EU. In particular, the new method's potential to strengthen democracy and the parliamentary nature of EU governance has been recognized. However, in reality, slightly different results have been produced. The Spitzenkandidaten mechanism turned out to be a formula based on immature solutions and electoral behavior and did not result in a clear reinforcement of the democratic factors of European integration. Instead, it has proved to be one of the expressions of inter-institutional rivalry, in which the intergovernmental European Council did not allow its competence for the appointment of the Head of the Commission to be diminished. The Commission itself, led by Jean-Claude Junker, in an attempt to exploit its ,democratic" origins in 2014, has become more of a political than a managerialadministrative body. In 2019, the Spitzenkandidaten mechanism was not re-implemented, despite forced attempts of the European Parliament to do so. It seems that pragmatism has prevailed, with a clear goal - to protect one's own prerogatives.
\end{abstract}

Keywords: Spitzenkandidaten, European democracy, European Parliament, interinstitutional balance, European Commission.

\section{Introduction}

The assessment of the Spitzenkandidaten mechanism's application (or rather, lack of application) in 2019 invokes (not for the first time) the issue of interinstitutional cooperation and democracy in the European Union (EU). The functioning of the EU's democratic mechanisms has been repeatedly discussed and assessed by academics, politicians and publicists, and the conclusions of various research centers and experts have never allowed a coherent approach to be 
established. It can be noted, however, that the resurgence of the current issue's exploration usually took place with the occurrence of a situation or event with a democratic explanatory potential. These were, often, elections to the European Parliament (EP), documents introducing institutional changes assessed concerning their democratic nature, or the activity of Member States regarding the observance of democracy in the EU. European Parliament elections held in May 2019 also served as a catalyst for further discussions on the observance and strengthening of the democratic rules of the European integration process and their importance in shaping interinstitutional relations.

The analysis in the submitted article concerns not so much the democratic nature of the EU's institutional solutions as the Spitzenkandidaten mechanism, which has become challenging in the process of implementing the democratic rules in the EU after the changes introduced by the Lisbon Treaty (LT).

The hypothetical assumption is that the Spitzenkandidaten mechanism, despite its potential to influence the EU political system, especially its democratization, has in fact proved to be an instrument used for pragmatic inter-institutional struggle for power.

In order to conduct the research, an institutional and legal method will be used, coupled with the Rational Choice Institutionalism theory, which makes it possible to clarify the role of the institutions and mechanisms of interinstitutional cooperation in the political space of the European Union.

\section{Democratic Dilemmas of European integration.}

Establishing any facts concerning the democratic state of the European integration process is one of the most confusing and difficult to interpret challenges for researchers. Even if one assumes that democracy itself is puzzlingly complex and makes it difficult to find its unambiguous, formerly clearly defined meaning, the conditions penetrating the integration mechanisms imply an increased inconsistency of interpretation and application (Sartori, 1998; Held, 1987; Held, 1993; Held, Koehler, 1998; Olsen, 1996; Wierzchowska, 2013).

The complexity of an inclusive political system constitutes the reality of the process of exercising power in the EU and means that traditional patterns of democratic rules of the game cannot be simply reflected here. We are therefore dealing with an intensification of the problem, which results not only from the lack of precision and complexity of the phenomenon of democracy 
itself, but also from the incompatibility of the circumstances in which the EU operates in, with those which constitute the traditional environment for the implementation of democratic state processes ${ }^{1}$.

For the founders of the European Economic Community (EEC), concern for the democracy of the institutional and axiological environment was not a priority. Pragmatism and the achievement of economic goals were the most important both for the political elite and for the societies. It is well known that Jean Monnet, who, in his diaries, stated that European integration could only start and develop only without democracy. One could say that there was no 'widespread appetite' for the common idea of Europeanness, and the economic freedoms provided by the common market did not build a sense of community, leaving Europeans rather indifferent to the activities undertaken by the political elite (Azmanova, 2017, p. 41). Moreover, strengthening democracy at the national level was, at that time, much more important than seeking it in a European angle. Securing the smooth functioning of democratic national mechanisms was to be guaranteed by integration processes, which did not determine the construction of a European democratic structure. Alan Milward called this historic process The European rescue of the Nation - States (Milward, 1992). This is well illustrated by the circumstances and motivations for the admission to the European Communities of countries such as Greece (1981), Spain and Portugal (1986). The idea that these countries' membership in the EEC will strengthen their transition from authoritarian regimes to democracy has been repeatedly stressed. The Community was supposed to create and support democratic aspirations in countries, not the other way around.

This approach was possible as long as integration concerned mainly the economy. The transition to a political union meant that the technocratic legitimacy and passive consent of the Europeans to the actions of European authorities is no longer sufficient. The direct elections to the European Parliament, introduced as early as 1979, have not changed the democratic reality in the Communities. They have become a symbol of the democratic nature of the European integration process and, at the same time, a spark of hope for the creation of a truly European public opinion,

\footnotetext{
${ }^{1}$ A lot of threads have already been developed about democratic rule and rules that should be met for their effective implementation, e.g: From a political science and democratization perspective, however, liberal democracies require horizontal accountability. Elected authorities must be checked and balanced by independent state institutions to prevent transgressions and right violations". (Ezzat, Fayed, 2020, p.108)
} 
which is essential for the emergence of a democratic demos ${ }^{2}$. While they are still a symbol of European Integration, the latter spark of hope can be described as postulatory thinking, rather than realistically implemented project.

From the point of view of democratic governance, the EU suffers from many issues. For instance, one might notice the problems of democratic legitimacy, democratic accountability of decision-makers, the mentioned lack of political community or lack of real civic participation. As a result, the term "democratic deficit" was coined to reflect the state and manner of application of democratic mechanisms in the European ${ }^{3}$ integration process. It is most often defined as a problem that has arisen as a result of the transfer of decision-making powers from the national to the European level, but without the creation of an efficient and effective control mechanism allowing for direct accountability of decision-makers by the recipients of decisions. This way, one of the most important patterns of democratic political life, consisting of accountability and the possibility to dismiss representatives and decision-makers who govern on behalf of the general ${ }^{4}$ public - fails. In the EU, the decision-making process has been entrusted to the representatives of the national executive governments, who, in cooperation with the EP and advisory bodies create law which is directly applicable in all member states. However, the same decision-makers are not directly accountable for their actions at the European level, which creates a hole in the democratic accountability mechanism. From the perspective of a traditional democracy, the mechanism based on the tripartite system is violated, which can be considered as one of the gravest sins committed against a democratic political system.

\footnotetext{
${ }^{2}$ This issue can be interpreted in different ways, due to the ambiguity of the term "demos". For the purpose of explaining democracy in the EU, it can be assumed that building a demos is a process of "(...) involving citizens and their sub-national level organizations in the mechanisms which shape the functioning of the European Union and its member states - the latter directly resulting from participation in the European Union. See: (Nowak-Far Artur, 2012, p. 22.) It means creating a common political identity, which is expressed in activity at European level.

${ }^{3}$ As Konstanty A. Wojtaszczyk explains, the very notion of democratic deficit is controversial because of the tendency to identify the EU with the state structure: See: (Wojtaszczyk, 2012, p. 15).

${ }^{4}$ The issue of accountability to the voters is mainly the concern of the Council's members. Heads of states and governments are officially accountable to their national parliaments and electorates. Even partial responsibility is limited, as any minister attacked for taking inappropriate action may use the necessity to act in accordance with the Union's decisions as a shield. The ministers of each country gather depending on the issue ( The General Affairs Council consisting of the foreign affairs ministers of the fifteen countries or the Special Council, i.e. the Ministers of a specific branch). The Council is characterized by a lack of a permanent composition, a rotating chairmanship and secret sessions.
} 
However, does democratic deficit fully allow to understand the nature of the EU's democracy? It seems that the problem of democracy in the EU from the perspective of its deficit already imposes a restriction resulting from the requirement to look for negative aspects, which are intrinsic to the term "deficit". There is no room for positive insights which would allow to view the EU in the light of positively functioning democratic solutions, worthy of a supranational political ${ }^{5}$ structure. Therefore, is democracy in the integration process really an impossible state? Or should the approach be changed and the specificity of the EU's political system be taken as a starting point, so as to tailor the democratic suit to its needs? There is another possibility, which would make it necessary to accept that the EU will not meet the requirements of democracy, but which offers other advantages in terms of greater decision-making flexibility or national independence.

Trying to put the above considerations in order, one can look at democracy in the integration process in relation to its two essential attributes: sovereignty and supranationalism. Together with the principle of democratism, they form the vertices of a triangle which, analyzed according to Dani Rodrik's impossible trilemma, indicates that it is not possible to fulfil all three objectives, which in this case would be to preserve a strong, sovereign and democratic nation state built into an equally strong and resilient supranational structure developing towards supranational democracy. The question concerning the plausibility of democratization of the EU remains. The chances are low if we want to maintain the status quo related to the current position of the nation state in the integration structure (not to mention, the tendency to strengthen its role).

\footnotetext{
${ }^{5}$ The theoretical aspects of European democracy are addressed, among others, by Erik Oddovar and John E. Fossum, pointing out that in order to understand the nature of European democracy, due attention needs to be paid to the theory of democracy, including consideration of the need for a new approach to interpret new democratic trends in Europe: See: (Oddovar, Fossum, 2012, pp. 201-202.).
} 
Figure 1

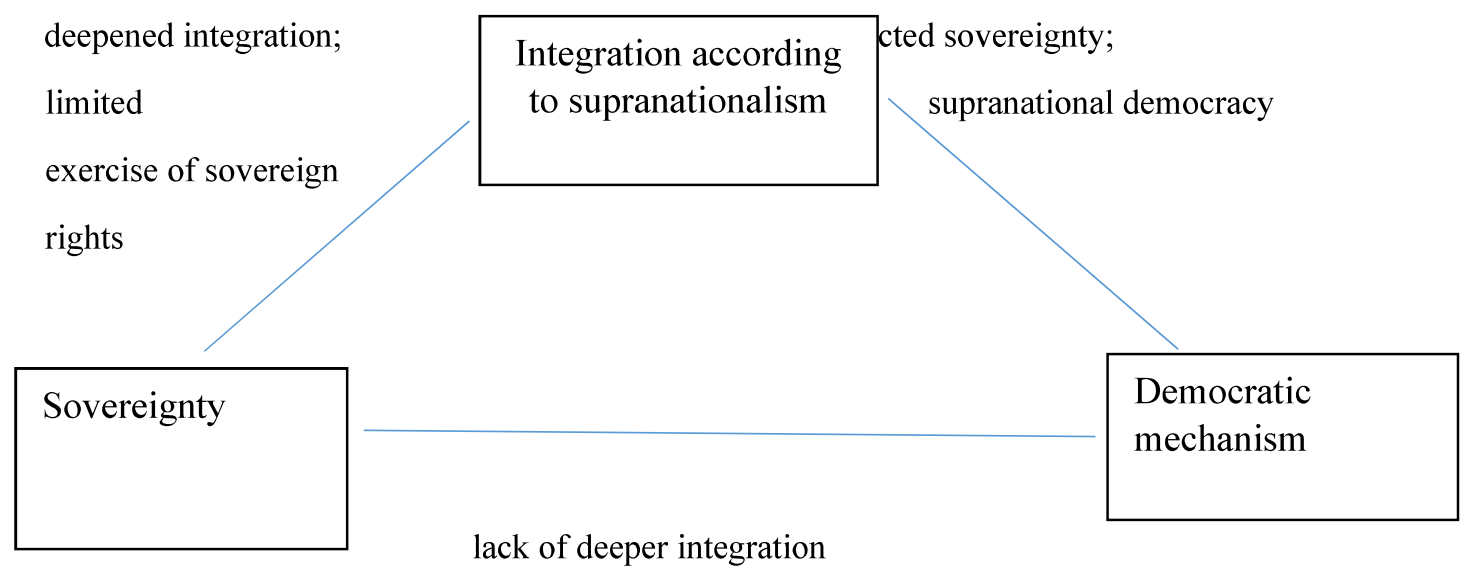

(Sovereignty remains structurally and functionally intact and the formula of a democratic nation state is preserved)

Source: own elaboration on the basis of: (Rodrik, 2005; Rodrik, 2011) and (Hardt, 2013 in: Grosse, 2013, p. 72).

When sovereignty is compared with the principles of supranationalism and the mechanisms of democracy, we are faced with the following options:

- $\quad$ achieving supranationalism with the abandonment of sovereignty and the creation of supranational democracy mechanisms;

- achieving supranationalism by redefining the concept of sovereignty (limiting the exercise of sovereign rights): it may result in expanded cooperation of a supranational nature with a simultaneous redefinition of the approach to the functioning of national democracy mechanisms;

- $\quad$ preserving sovereignty indivisibly (without limiting the exercise of sovereign rights), without striving for supranationalism, thus preserving national democratic mechanisms.

As in the case of the economic trilemma - the original Rodrik's impossible trilemma (Rodrik; 2005, 2011) ${ }^{6}$, in essence, it becomes impossible to reconcile all aspirations: deep

\footnotetext{
${ }^{6}$ According to Rodrik's concept deep economic integration requires the elimination of all transaction costs faced by traders and financiers in their cross-border transactions. National states are the primary source of such transaction costs. They generate national risk, create regulatory discontinuities at the borders, prevent global regulation and supervision of financial intermediaries, and make the lender of last resort a distant dream. The malfunctioning of the global financial system is closely linked to these specific transaction costs. What can, therefore, be done? One option is to seek global federalism, in which the scope of (democratic) policy can be adjusted to that of global markets. In
} 
supranational economic integration is possible only in two scenarios: with the (limited) preservation of sovereignty, but with the loss of democratic mechanisms; or with the preservation of democratic rules, but with the renunciation of sovereignty, thus creating a federal community ${ }^{7}$. It is also possible to abandon the supranational path and remain on the traditional path of intergovernmental cooperation, thus preserving the fully democratic and national character of the countries.

It therefore seems that the transfer of democratic models to the European integration process is strongly conditioned by the existence or lack of certain phenomena. This is not an obvious, uncontested procedure that can be carried out under any circumstances, especially using when activities used are restricted or isolated from the whole project. Democracy, no matter where it is developing, needs suitable conditions to grow, which cannot consist the political will of its elite participants alone. Or are we, as Hagen Schulz-Forberg and Bo Strath suggest, hypocritical about the debate on the democratic aspect of European integration? Are we not faced with yet another triangle, with criticism, crisis, and hypocrisy as its vertices? These vertices are simultaneously points of reference in EU analysis. (Schulz-Forberg, Strath, 2012, p. 3). As the aforementioned researchers emphasize, the idea of democratization through market is historically implausible, especially concerning the emergence of democracy in Europe. What determined

fact, however, this cannot achieved on a global scale, and even among like-minded countries, as the EU experience shows. Another option is to maintain the nation state and make it receptive only to the needs of the international economy. This would be a state that would pursue global economic integration at the expense of other national objectives. The nineteenth-century gold standard may serve as a historical example. The collapse of the Argentine convertibility plan of the 1990s is a contemporary illustration of its inherent incompatibility with democracy. Finally, we can lower our ambitions in terms of how much international economic integration we can (or should) achieve. Therefore, we are entering a limited version of globalization, which was the post-war Bretton Woods regime (with its capital control and limited trade liberalization). Unfortunately, it became a victim of its own success. We forgot about the compromise inherent in this system, which was the source of its success. Any reform of the international economic system must face the trilemma. If we desire more globalization, we must either give up democracy or give up certain national sovereignty. Pretending that we can have all three at once leaves us in an unstable no man's land. Based on: (Rodrik, 2011). Globalization in relation to economic phenomena brings the most visible but also often undesirable effects. As Mario Arturo Ruiz Estrada writes in the context of the 2007/2008 recession: We assume that the epicenter that is connected to all markets (country / region) is the GDP growth rate of the U.S .; at the same time, each market has a large number of windows refraction. Economic waves are generated first by plotting a single value (growth rate) in each window refraction and joining each single value located in each window refraction by straight lines from the epicenter to the last window refraction in each market (...); we call this concept "windows refraction links.(Estrada, 2014, p. 250)

7 One of the democratic "gains" which implementation possibilities are becoming very limited in transnational conditions is civic participation. As J. Czapiński and T. Panek write: "People participate in democracy not only when they participate in organizations or do something jointly for others or for the benefit of their community, but also when they gather, discuss and decide on something together".(Czapiński, Panek, 2015, p.338). 
European democratization were social conflicts and bottom-up processes leading to protests, to which there were then attempts to find solutions, not to establish market economies ${ }^{8}$. So how, following this line of reasoning, can one expect the almost automatic emergence of democracy in the EU when there have been no European speeches or unrests which would have wider than national effect? The problem of democracy in the EU therefore lies not only in the appropriate shaping of the institutional system. It also reaches deeper - to the origins of democratization processes.

Leaving the dilemmas of democracy itself behind and moving on to the next part of the study, one may wonder whether the introduction of a mechanism for identifying the main candidate for the presidency of the European Commission (EC) before the EP elections can change anything in the democratic landscape of the European integration process. Can the implementation of a democratically important solution in an unprepared environment, influence the formation of the democratic canon of an institutional system that does not have a definite direction?

\section{Institutional and Legal Conditions of the Spitzenkandidaten mechanism}

The procedure for the main candidates was first used in 2014 to elect the Commission's President Jean-Claude Juncker. However, it should be stressed that the procedure did not (and still does not) have a clear Treaty basis, apart from art. $17 \sec 7$ TEU, which states:

"Taking into account the elections to the European Parliament and after having held the appropriate consultations, the European Council, acting by a qualified majority, shall propose to the European Parliament a candidate for President of the Commission. This candidate shall be elected by the European Parliament by a majority of its component members. If he does not obtain the required majority, the European Council, acting by a qualified majority, shall within one month propose a new candidate who shall be elected by the European Parliament following the same procedure".

The application of the mechanism therefore stemmed from an agreement between the heads of state and governments of the European Council, the European Parliament and the European

\footnotetext{
${ }^{8}$ However, it is difficult not to see the link between social unrest in 19th century Europe and growing capitalism. However, according to the authors, what was the leading force was the desire to gain influence in the developing social, economic and political space.
} 
political parties, concluded before the 2014 European elections ${ }^{9}$ and not from the direct application of any provision of the Treaty.

The 2014 agreement could be considered as an expression of the EP's systematic and successful march towards strengthening its position in the institutional system of the Communities/European Union and parlamentarization of the EU political system. The history of these efforts is longer than the formal existence of the Union itself, but the European Parliament emerges as the clear victor of the last 20 years. Starting as an indirectly-elected consultative assembly, it could co-decide on the vast majority of EU legislation, its budget and the appointment of the European Commission.

The progressive process of parliamentarization of EU governance was therefore one of the main structural changes in the EU 's institutional system (Schimmelfennig, 2014). In 2012, the European Parliament formulated a resolution ${ }^{10}$ calling on European political parties to „,nominate candidates for President of the Commission" and expressed the hope that these candidates will play a „leading role" in the parliamentary election ${ }^{11}$ campaign. At that time, the EP suggested an interpretation of art. 17. It argued that changing the literal contents of the article from 'approve' to 'select' meant that a choice must be made from multiple candidates, instead of simply making the European Council's decision valid. The EP also expressed its expectation that ,in this process, the candidate for President of the Commission presented by the European political party with the most seats in Parliament will be considered first". The proposed solution did not 'promise' the chairmanship of the winning party, but suggested that its candidate should be 'ready' to gather sufficient parliamentary support (Tilindyte 2019, p. 4).

\footnotetext{
${ }^{9}$ Considering the legally non-binding acts, one might mention the Declaration 11 on art. $17 \mathrm{sec} .6$ and 7, annexed to the Treaties, which specifies that the European Parliament and the European Council are "jointly responsible" for the smooth running of the process leading to the election of the President of the Commission, and the relevant consultations "will focus on the background of the candidates". Furthermore, Declaration 6 on art. $15 \mathrm{sec} .5$ and 6, art. $17 \mathrm{sec} .6,7$, and 18 of TEU mention the need to respect the "geographical and demographic diversity" of the EU and its Member States in this process.

${ }^{10}$ Resolution of 22 November 20102 in the 2014 EP elections 2012/2829(RSP)

${ }^{11}$ The EP resolution follows an earlier State of the Union Address on 12 September 2012 by the then President of the Commission, J.M. Barroso, stressing that the presentation by the European political groups of their candidates for President of the Commission would be "an important means to deepen the pan-European political debate": European Commission, 12 September 2012, 'State of the Union 2012 Address', http://europa.eu/rapid/pressrelease SPEECH12-596 en.htm; za: The Spitzenkandidaten procedure. Genesis and nemesis of a constitutional convention? https://njb.nl/Uploads/2015/9/LLM-Thesis---LLM-European-Law---Paul-W.-Post.pdf
} 
These changes in the way of electing the head of the Commission can also be found in the successive Treaty reforms, starting with the changes introduced by the Treaty of Nice (2001). Until the Treaty's entry into force in 2003, the candidate for President was nominated by the member states' governments, and the EP merely approved the nomination. The procedure continued with the election of individual Commissioners until the whole body and its President were approved by common accord (then applicable, art. 214 sec. 2 TEC). The Treaty of Nice has introduced modifications to this procedure, mainly to clarify the meaning of "member states' governments". ${ }^{12}$. Since 2003, art. $214 \mathrm{sec} .2$ TEC has included a provision which specifies that, as a first step, the candidate for President shall be nominated by the Council, acted by a qualified majority, comprising the heads of state or Governments, and such a decision requires the approval of the European Parliament. Also in the final stage, the President and the other members of the Commission were appointed by the Council, acting by a qualified majority. According to Jan Barcz, the election of the President and the other members of the Commission by the Council, acting by a qualified majority, significantly reduced the possibility of choosing a politically weak candidate, as was the case with Jaques Santer (Barcz, 2017, p. 223). The introduction of the majority voting element in the nomination procedure at the beginning and at the end of the process was undoubtedly a democratizing effect. Especially when compared to when the candidate was proposed by the governments of the member states, using stricte intergovernmental, behind-thescenes procedures ${ }^{13}$. However, despite majority voting, in practice the search for consensus has remained the norm. As a result, the appointment process remained opaque and was repeatedly compared to "changing seats" between governments behind the scenes, often resulting in so-called „lowest common denominators", which can be understood as the choice of the least controversial candidate (Penalver García, Priestley; 2015, p. 12) ${ }^{14}$.

\footnotetext{
${ }^{12}$ Treaty of Nice amending the Treaty on European Union, the Treaties establishing the European Communities and certain related acts; http://oide.sejm.gov.pl/oide/images/files/dokumenty/traktaty/Traktat_z_Nicei_PL_1.pdf

${ }^{13}$ However, the strengthening of the EP's position was already apparent previously. In line with the rule that the EP is always one step ahead of the Treaty change, emboldened by its first direct elections (1979), the Parliament held a symbolic vote on the candidate for President of the Commission in 1981. Since, future presidents present their programme to Parliament. In 1994, parliamentary hearings for commisioner candidates were introduced (Westlake, 2016, p. 36; Penalver García, Priestley, 2015, p. 44.)

${ }^{14}$ See also: (Westlake, 2016; Baldoli et al., 2014).
} 
The Lisbon Treaty consistently strengthens the democratic potential in the procedure for the election of the EC President, primarily by linking the nomination of the EC President to the outcome of the European Parliament elections and by entrusting the election of the President to the European Parliament (previously, the Parliament only approved the nomination of the Council, which met in the composition of heads of state or governments). This strengthens the position of the European Parliament in the institutional system of the Union, which is usually interpreted in terms of the power to democratize the EU political system (Barcz 2017, p. 224) ${ }^{15}$.

Table 1

\begin{tabular}{|c|c|c|c|c|c|}
\hline & $\begin{array}{l}\text { Before } \\
\text { Maastricht } \\
\text { Treaty } \\
\end{array}$ & $\begin{array}{l}\text { Maastricht } \\
\text { Amsterdam } \\
\text { (1999) }\end{array}$ & $\begin{array}{l}\text { Amsterdam - } \\
\text { Nice (2003) }\end{array}$ & $\begin{array}{l}\text { Nice - Lisbon } \\
(2009)\end{array}$ & $\begin{array}{l}\text { After Lisbon } \\
\text { Treaty }\end{array}$ \\
\hline $\begin{array}{l}\text { Election of the } \\
\text { President of the } \\
\text { European } \\
\text { Commission }\end{array}$ & $\begin{array}{l}\text { Decision taken } \\
\text { unanimously by } \\
\text { the governments } \\
\text { of the member } \\
\text { states }\end{array}$ & $\begin{array}{l}\text { Decision taken } \\
\text { unanimously by } \\
\text { the governments } \\
\text { of the member } \\
\text { states, after } \\
\text { consulting the EP }\end{array}$ & $\begin{array}{l}\text { Decision taken } \\
\text { unanimously by } \\
\text { the governments } \\
\text { of the member } \\
\text { states, after EP's } \\
\text { consent }\end{array}$ & $\begin{array}{l}\text { Council decision } \\
\text { taken by QMV, } \\
\text { with the EP's } \\
\text { consent }\end{array}$ & $\begin{array}{l}\text { European } \\
\text { Council decision } \\
\text { taken by the } \\
\text { QMV, taking } \\
\text { into account the } \\
\text { results of the EP } \\
\text { elections; EP } \\
\text { consent }\end{array}$ \\
\hline $\begin{array}{l}\text { Election of the } \\
\text { European } \\
\text { Commission }\end{array}$ & $\begin{array}{l}\text { Decision taken } \\
\text { unanimously by } \\
\text { the governments } \\
\text { of the member } \\
\text { states }\end{array}$ & $\begin{array}{l}\text { Decision taken } \\
\text { unanimously by } \\
\text { the governments } \\
\text { of the member } \\
\text { states, after } \\
\text { consulting the EP }\end{array}$ & $\begin{array}{l}\text { Decision taken } \\
\text { unanimously by } \\
\text { the governments } \\
\text { of the member } \\
\text { states, after EP's } \\
\text { consent }\end{array}$ & $\begin{array}{l}\text { Council decision } \\
\text { taken by QMV, } \\
\text { with the EP's } \\
\text { consent }\end{array}$ & $\begin{array}{l}\text { European } \\
\text { Council decision } \\
\text { taken by QMV; } \\
\text { EP's consent }\end{array}$ \\
\hline
\end{tabular}

Source: based on: The Spitzenkandidaten procedure. Genesis and nemesis of a constitutional convention? https://njb.nl/Uploads/2015/9/LLM-Thesis---LLM-European-Law--Paul-W.-Post.pdf (accessed: 20 February 2020).

\footnotetext{
${ }^{15}$ Concerning the reform of the election of the President of the European Commission, see also: (Crombez, Hix, 2011, pp. 291-314).
} 
If one were to consider the direction of the changes introduced with regard to the European Commission, including the election of its President, reading only the Treaty provisions in isolation from other practices, one could deduct that democracy has been decidedly and unquestionably strengthened. However, as the EU is a complex system of formal and informal interinstitutional links, any institutional solution should be seen from the perspective of the system as a whole and in relation to previously existing solutions. Individual endeavors, then, even if with a significant democratic potential, will not strengthen the real democratic power of the system.

The procedure can therefore be assessed both in terms of its impact on the whole institutional structure, including its potentially democratizing nature, and the perspective of one of the main institutions: The European Parliament, the European Council or the European Commission. Conclusions may vary considerably, depending on whether a broader or narrower evaluation perspective was adopted. As stated by Laura Tilindyte, the evolution of the formal procedures for appointing the President of the Commission must be seen in the broader context of the significant changes, which have fundamentally shaped the institutional landscape of the EU. In addition to the continuous strengthening of the European Parliament as a directly elected EU institution, one should also mention the extended 'Presidency' of the Commission, the emergence of the European Council as a fully-fledged institution which allow us to define the general political directions of the EU, the development of European political parties and, above all, the continuous efforts to increase the legitimacy of the Commission and the EU as a whole (Tilindyte, 2019, p. $3)$.

Implementation of the Lead Candidate Mechanism in 2014 - Conclusions and Implications

The new legal conditions put in place for the election of the European Commission in 2014 enabled the European elections to be held in the same year in a modified environment. In preparation for this, the major political factions appointed their candidates for the post of Commission's President at the turn of 2013/2014, including: Jean-Claude Juncker (European People's Party), Martin Schulz (Party of European Socialists), Guy Verhofstadt (Alliance of Liberals and Democrats), Ska Keller and José Bové (European Green Party) and Alexis Tsipras (European Left). The other parties have not indicated their candidates.

The analysis of the election campaigns of the three main Spitzenkandidaten, Juncker, Schulz, and Verhofstadt, shows that an effort was made to present them in TV debates and 
distributed election materials. However, these efforts did not improve the poor electoral ${ }^{16}$ result. Voters did not feel more motivated to vote, even though they were aware that this choice may indirectly affect the future appointment of the European Commission President. The experiment was therefore only partially successful. The mechanism itself was used, but the effects, that is increasing public interest in European affairs and giving the European Commission more legitimacy, did not occur. This may be all the more disappointing as the 2014 European election were announced as an event of particular importance. The election's slogan, „This time it's different", referred to the new possibilities resulting from the modifications introduced by the Lisbon ${ }^{17}$ Treaty. The specific nature of the election stemmed from the particular political atmosphere at the time: with unsuccessful attempts to contain the refugee crisis, combined with the polarized European societies and political elites as a result of the eurozone crisis. In other words, it was expected that the election taking place in such circumstances would be different and would become a transformational event in EU policy (Christiansen, 2016, p. 993). The electoral effect manifested itself as an increase in the participation of Eurosceptic groups and, as a result, an unfavorable political arrangement for supporters of deeper integration ${ }^{18}$. Voter turnout was yet another negative effect, as it continued the declining trend in the participation of European citizens in EP elections ${ }^{19}$.

The assumption was that the procedure for appointing the main candidate would be a testament to the search for otherness and novelty in the integration process, reviving its public

\footnotetext{
${ }^{16}$ Nine television debates were held between the Spitzenkandidaten in April and May 2014, in different configurations and from various member states. No debates were held or broadcasted in Poland.

${ }^{17}$ Many commentators argued that the elections were indeed different and just as the year 2013 was declared the European Year of Citizens, 2014 could go down in history as the European Year of Spitzenkandidaten; see: Mahony Honor., The Spitzenkandidaten Coup, „EUobserver” 4 January 2015, https://euobserver.com/review-2014/126456; accessed: 23.02.2020

${ }^{18}$ As Beata Kosowska-Gąstoł noticed: "The Euro-enthusiasts were the dominant force during the eighth term EP, the Eurosceptic MPs have become more important figures, compared to the previous term. While previously they had not exceeded $20 \%$ of the members of the European Parliament, after the 2014 elections, they already accounted for more than $28 \%$ of the body. This percentage includes soft and hard Eurosceptics." (Kosowska-Gąstoł, 2019, p. 129). Representatives of the extreme right, also considered Eurosceptics, whose attitude towards the European integration can be considered more than Eurosceptic (55 seats were filled by representatives of such groups as the French National Front, the Italian Northern League, the Freedom Party of Austria, the Dutch Party for Freedom, the Polish Congress of the New Right, the Greek Golden Dawn, Jobbik from Hungary, MPs from UKIP, the Danish People's Party, the True Finns, MPs from the Latvian Order and Justice (Kosowska-Gąstoł, 2019, p. 129, after: (Oliver, 2014, p. 1543).

${ }^{19}$ The turnout in the European Parliament election held on $22-25$ May 2014 was $42.61 \%$ (43\% in 2009).
} 
space and showing how the mechanism of national parliamentary democracy is applied at the level of the EU political system.

The manifestations of the new system's impacts on the functioning of the EU's democratic mechanisms are multi-dimensional.

During the 2014 campaign, the importance of European issues has increased, allowing citizens to follow specific EU-related policies and discussions more closely. It is estimated that daily, a thousand press articles mentioned Jean-Claude Juncker and Martin Schulz (Garcia et al., 2015), while several thousand tweets mentioned the interviews and TV debates among the candidates, as well as their unprecedented tour across the EU. The efforts made did not improve the poor electoral ${ }^{20}$ result. In a post-election survey conducted in fifteen member states, $13.5 \%$ of respondents indicated they were aware of the main candidates (Hobolt, 2014). Furthermore, 41\% of the respondents expressed their awareness of the Spitzenkandidat process, that is, voting for parties in the European elections which gave indirect support to a specific candidate for President of the Commission. However, as a result, according to the Eurobarometer survey conducted after the 2014 election, only 5\% of European citizens exercising their right to vote mentioned that they went to the ballot box to have, influence over the election of the President of the European Commission" (Eurobarometer, 2014).

To sum up the electoral issues: in the 2014 European election, for the first time, citizens were able to decide, indirectly, who will hold the most important executive position in the EU. When Jean Claude Juncker was elected President of the Commission by an overwhelming majority of 422 votes in the Strasbourg EP plenary session, his legitimacy was doubly confirmed (Westlake, 2016). On the one hand, President Juncker's legitimacy can be attributed to the nomination by the European Council. On the other hand, by representing the European political party that won the elections and obtained an absolute majority in the EP, he had a democratic mandate. Thus, the elements of the presidency and parliamentarianism were combined in the EU political system,

\footnotetext{
${ }^{20}$ In April and May 2014, nine television debates took place between the Spitzenkandidaten, in different configurations, broadcasted by TV stations from different member states. No such debates were held or broadcasted in Poland. The final debate of the candidates was broadcasted on 49 television channels across Europe, however, the viewership was not high (in most cases - less than half a million viewers). This, according to the commentator of the EUobserver portal, may have been a sign of a moderate interest in the debates (and the Spitzenkandidaten themselves) in European public opinion: Benjamin Fox, The Spitzenkandidaten - this time was it different, „EUobserver”, 26 maja 2014, http://euobserver.com/news/124235 (accessed 28 February 2020).
} 
(Dinan, 2016). The Spitzenkandidat process has begun to be seen as a significant factor in the development of European democracy. At the same time, this process was also seen as an initiative that could lead to the federalization of the EU.

Another effect, often noted by experts, has been the politicization of the Commission. The election of Jean-Claude Juncker on the basis of the Spitzenkandidaten mechanism has made the new President a highly politicized head of the European Commission, who intended to establish the European Commission as a more political, rather than managerial-administrative body ${ }^{21}$. Although this trend was not a new one, as it can be traced back to the ratification of the Maastricht Treaty and the Danish Maastricht Treaty referendum ${ }^{22}$, the political nature of the Commission has certainly been strengthened by the new President, who reorganized the internal structure, by making it more hierarchical and by giving himself greater potential for political leadership through strong leadership (Nugent, Rhinard, 2019, pp. 203-204). The new President emphasized his position and presented himself as a confident, assertive leader with clear ideas and visions for the future of the EU. Finally, both as a candidate and later as an official, he clearly expressed his intention to serve as political president (Ingeborg, 2019, p. 3) ${ }^{23}$.

Overall, in the ideological, organizational and administrative areas, the European Commission has become much more political in the 2014-2019 term (Nugent, Rhinard, 2019, p. 203). The politicizing of this institution manifested itself primarily through bureaucratic neutrality in the Commission's human resources management being replaced by political considerations. This raises a very important and unsettling question: is a candidate selected in a procedure akin to general elections, by emphasizing his legitimacy in a more decisive manner in pursuing his aspirations to strengthen his position does not, in effect, contribute to transforming the original,

\footnotetext{
${ }^{21}$ There is a lively discussion on the difference between the political and the technocratic. As Sophia Russack notices, after Claudio Radelli, this difference can be based on the assumption that what is political is connected with values, while what is technocratic is connected with expert activity. (Radaelli, 1999, after: Russack, 2019, p. 2)

${ }^{22}$ This is the first time that citizens have so clearly shown their opposition to the influence of the integration process, for which the technocratic elite of the European Commission was responsible (Russack, 2019, point 3). Also, seeking ways to strengthen the democratic legitimacy of the Commission by bringing it closer to the EP in its area of responsibility has made it more political.

${ }^{23} \mathrm{An}$ example of this trend can be seen in appointment of Martin Selmayr, first as Chief of Staff (2014-2018) and then as Secretary General (2018-2019). The promotion of Selmayr from the position of Chief of Staff of President JeanClaude Juncker to the highest official of the Commission has caused controversy and agitation among some MPs. Parliament adopted a resolution calling on him to resign. After a five-month inquiry, Emily O'Reilly, the European Ombudsman, said that the Commission had "twisted and perhaps even violated the law" by giving Selmayr a quick two-step promotion. However, the Commission rejected this criticism( Ingeborg, 2019, p. 3).
} 
expected strengthening of democratic mechanisms into authoritarian action or at least an urge to strengthen individual ambitions at the expense of general public?

Junker himself underlined the politicization of his position in his first State of the Union speech at the EP plenary session in Strasbourg in 2014, stating that:

"Having campaigned as a lead candidate, as Spitzenkandidat, in the run up to the elections, I had the opportunity to be a more political President. This is why I said last September before this House that I wanted to lead a political Commission. A very political Commission. I said this not because I believe we can and should politicize everything. I said it because I believe the immense challenges Europe is currently facing - both internally and externally - leave us no choice but to address them from a very political perspective, in a very political manner and having the political consequences of our decisions very much in mind.” (Juncker, Jean-Claude, 2014).

Concerning the changes in interinstitutional relations, the EP won with the European Council on an institutional level, setting an important precedent for the future elections of the President of the Commission (Hobolt, 2014)." As the European legislator imposed the Spitzenkandidat process, the European Council became of secondary importance (Kassim, 2016). It can be suggested that the Spitzenkandidat process has modified the institutional balance of the EU towards the model of a parliamentary system.

However, cooperation between EU institutions has been tightened since 2014. Regular meetings were held between President Juncker, First Vice-President Timmermans and EP President Martin Schulz; The President of the PPE Group, Manfred Weber, and former Chairman of the Socialists and Democrats (S\&D), Gianni Pittella. This group was named „G5” (Christiansen, 2016, p. 1003). A coalition between the EPP and S\&D was established, at the level of the executive and legislative bodies. The groups' representatives coordinated their work and reached common conclusions. According to Dinan, the Spitzenkandidaten process is a step towards establishing a more consensual cooperation between the Commission and the European Parliament, making it more sensitive to the interests of the EP (Dinan, 2016, p. 111). It is thus a key element in creating closer institutional ties.

The European Commission itself was interested in the new solution, seeing it in the context of strengthening its position in the democratic European order and as an opportunity to alleviate the constant allegations of being responsible for legitimizing technocracy. It was in the EU's interest to strengthen the relationship between the elections involving EU citizens and the process 
of electing the President, especially if it had a weakening effect on the intergovernmental European Council (European Commission 2013). This view of the lead candidate system can be supported by the statement that the real influence of the Spitzenkandidaten can be seen not in the elections but in the institutional policy of the European Union. Its institutional actors - the Council, the Commission, the Court and the Parliament - are involved not only in disputes over policy - they also compete for the division of power and competences (Schimmelfennig, 2014).

Weighing the positive, negative, and neutral impacts of the mechanism applied in 2014, it can be said that it has not led to significant changes. However, from 2014 election point of view, one should consider not only the degree of efficiency and effectiveness, but also the potential of a promise for the future, in which the European Commission would have a stronger citizen support.

\section{Implementation of the Spitzenkandidaten mechanism in 2019 - an inter-institutional} political game

The 2014 experiment, even if it was not a breakthrough in the functioning of the mechanisms of parliamentary democracy in the EU, certainly strengthened the EP's motivation to repeat it in the next elections. Therefore, as the European elections in 2019 approached, the European Parliament, in its Decision of 7 February 2018 on the revision of the Framework Agreement on relations between the European Parliament and the European Commission, stated that it was prepared to reject any candidate for President of the European Commission who was not elected as the lead candidate (Spitzenkandidat) of the European political party concerned before the 2019 European Parliament elections. The document repeatedly references the democratic rules of EU political life, including representative democracy enabling the participation of European citizens in the public life of the EU or the importance of parties at European level in shaping European political awareness.

Other arrangements of the agreement concerned the following principles of cooperation between the institutions:

- politicians who are members of the current Commission should be able to run in European Parliament elections and be nominated by the European parties as "lead candidates";

- The President of the Commission is obliged inform the Parliament of the measures taken to ensure that Commissioners participating in EU electoral campaigns respect the principles of independence and integrity; 
- The Commissioners running in elections will not be allowed to use the Commission's human and material resources for any electoral campaigning activities.

The document also highlights the success of the Spitzenkandidaten procedure of 2014.

However, the agreement concluded did not strengthen the future status of the lead candidate procedure. The solution has not been introduced in the Treaty. In addition, the European Council considered that it could not guarantee that its candidate would be one of those previously elected by the parties. Referring to the provisions of the Treaty, the leaders stated that the process of electing the President of the EC is not automatic and the presentation of the candidate falls under the autonomous competence of the European Council. The leaders ignored the EP's warning, which signaled that it would not accept a candidate for the head of the EC after the election, if the candidate was not nominated by one of the European parties.

Disregarding the discouraging statements of the European Council, as in 2014, just days before the 2019 election, the political groups of the EP indicated their main candidates: Manfred Weber (EPP), Frans Timmermans (PES), Ska Keller and Bas Eickhout (European Green Party), Jan Zahradil (European Conservatives and Reformists), Nico Cué and Violeta Tomić (European Left). The liberal (ALDE) group acted differently and did not present their candidate. Instead, Guy Verhofstadt appointed the team of liberal leaders. It was the result of the disappointment with the results of the practical application of the system in 2014.

A strong polarization of political positions was observed during the 2019 campaign. This was evident in numerous television debates between competing candidates, and in particular during the debate in the EP plenary hall in Brussels on May 15, 2019 (European Parliament, 2019a). In the debate, the Greens and the European left positioned themselves as a political alternative to the European mainstream. This contrasted with the position of Manfred Weber, the conservative candidate who tried to present himself as the guarantor of the EU's success. In turn, the socialist Frans Timmermans signaled an agreement with the Greens and liberals on various political issues, thus announcing possible alliances that could gain a political majority after the elections. Liberal candidate Margrethe Vestager presented her program as being in line with the two most likely contenders for the presidency of the Commission, namely Weber and Timmermans, thereby indirectly offering herself as a potential compromise candidate. The process of selecting candidates has also proved susceptible to undemocratic meanders. The European People's Party with the best chance of winning at the Helsinki congress in early November 2018 
nominated Manfred Weber. His opponent was Alexander Stubb, former prime minister of Finland, to whom Weber offered open public debate on the program. But later, confident of support from Chancellor Merkel and most German MEPs, he rejected this suggestion. For the sake of appearances, a debate lasting just over half an hour was organized, which, however, did not change the decision already settled in the privacy of the office.

In the case of European Socialists and Democrats, the situation was resolved without conflicts - Maroš Šefčovič, the only opponent of the then chairman of the Commission Frans Timmermans, resigned and supported the Dutchman (Borkowski, 2019, pp. 202-203).

However, the elections to the European Parliament held in May 2019 did not soften the political mood and did not lead to the immediate adoption of a solution to the election of the new head of the Commission. The peculiar second part of the interinstitutional rivalry game has begun.

The final election result strengthened the strategy of the European Parliament, which, emboldened by the higher turnout, proceeded its activities according to the rules established in 2014 with regard to the Spitzenkandidaten mechanism. Thus, the EP continued the internal party and political rivalry to select a compromise candidate, similarly to the government formations. It suggested a political agenda for the Commission and stipulated that he would only accept as a candidate for President someone who "presented his/her agenda and personality ahead of the elections and engaged in a pan-European campaign ". (Parliament, 2019b).

The European Council, unlike the European Parliament, did not act as if the game was already taking place in a well-defined arena. Its strategy was unclear from the beginning. It tried to use time, activated resources and strategies that pushed the decision back to the natural arena, which does not take into account the Spitzenkandidaten mechanism, for the selection of the candidate for the President of the Commission. As a consequence, an intensified emphasis on party and political rivalry could also be observed inside the European Council. The disputes concerned the candidacy of Manfred Weber, who was accused of lack of government experience and charisma. In turn, some Central European countries rejected Timmermans as a compromise candidate due to his harsh criticism of the rule of law as a commissioner. French President Macron, on the other hand, made himself known as a "thrifty and flexible entrepreneur", turning his opposition to the Spitzenkandidaten process into success: he stressed Weber's unsuitability for the position and paved the way for a joint compromise in the Council. Its aim was to restore the Council's position from before 2014 (Euractiv, 2019). 
Weber was a "tough" candidate for Macron to be accepted. He favored Victor Orban, did not speak French, was supported by a country with federal tendencies. His position was definitely weaker than Juncker's. This personal puzzle was complicated by the reluctance to support him by Timmermans, who, after the elections, was in the position of the candidate of the losing party and could no longer fight for the chairmanship of the Commission. Still he did not want to support Weber at the same time, as Schulz was willing to support his predecessor. Timmermans was finally supported by Angela Merkel following the agreement reached at the G20 meeting in Osaka on 28 and 29 June 2019. Weber was promised the position of President of the European Parliament (De Wilde, 2020, pp. 37-53). Unlike Weber, Timmermans had extensive national and European management experience and was fluent in French (as well as Dutch, German, English, Italian and Russian). This made him accepted by Macron and other skeptical national leaders, even though they did not support the Spitzenkandidaten mechanism (Högele 2019). Timmermans also had a "green light" from his native Dutch government and the Spanish government, which negotiated on behalf of the socialist group. Criticism however was Ireland, whose representative, Leo Varadkar, opposed Timmermans, arguing that he was not an EPP candidate, and therefore didn't have a mandate for this party's voters.

The liberal candidate Margrethe Vestager also turned out to be problematic candidate. She was opposed by representatives of the EPP for similar reasons as Leo Varadkar. Merkel additionally opposed Vestager, claiming that she was not a "real Spitzenkandidat", introducing herself in this way only after the elections (previously she was one of the members of the liberal "Team Europe").

It is not difficult to read from this picture that reaching a compromise among the presented candidates was very difficult. The final inter-institutional consensus was achieved by the election of Ursula von der Leyen, who had previously not been considered Spitzenkandidaten at all. She became the first woman to take the position of President of the European Commission (which made it difficult for socialists and liberals in the European Parliament to oppose her candidacy). In addition, she had experience in management and spoke several languages, so her competences could not be denied (De Wilde, 2020, pp. 37-53). Her candidacy satisfied the conservative majority as well as calmed the fears of Central European countries towards Timmermans.

It is clear from the course of the entire campaign, as well as from the post-election scuffles, that the candidacy of Manfred Weber was to a large extent a bone of contention. The EPP's "party 
choice" of Manfred Weber killed the Spitzenkandidaten process as two other candidates, socialist Frans Timmermans and liberal Margrethe Vestager, also had to be dropped despite actually enjoying wider support in the EU Council (Euroactive, 6/21/2019).

The way in which an agreement was reached has made it possible to emphasize the institutional superiority of the Council, interfering with both the right of the EP to elect its president and the right of the President of the Commission to designate positions in the Commission himself. In this way, not only the natural arena of the game, which was in force before 2014, was restored, but it was extended to the previously institutionalized spheres of (relatively) independent decisionmaking in the EP and the Commission. The Council also elected the permanent President of the Council and the High Representative without further coordination. The move limited the EP's room for maneuver in light of the delicate geographic, party-political and gender balance required in the personnel package covering key positions in the EU.

In the light of the presented facts, it is clearly visible that in 2019 the EP lost direct competition to the Council. President of the European Council Donald Tusk added that the Spitzenkandidaten process was never a "legal obligation" for EU leaders to follow, but that heads of state attempted to "respect" the votes of European citizens. The fact that EP did not fulfill its election promise, in which elections were presented themselves as an opportunity to exert a direct influence on the selection of the President of the Commission, should be read as a defeat of the EP. The claim that party-political rivalry and negotiations would produce the best-suited candidates was weakened by the Council's counterargument that the best-qualified person cannot be identified through party-political compromise. The Council made a kind of counter-revolution to what was introduced in 2014.

\section{Conclusion: Why did the system fail?}

The European Parliament election of 2019 did not confirm the efficiency and the democratizing impact of the lead candidate procedure. The German tabloid Build, which published the reaction to van der Leyen's candidacy, included very clear criticism of the mechanism: „Those who have always believed that the EU is a bloated, bureaucratic giant with unclear structures, ruled by a clique, have just had their beliefs reassured".

The heads of state who met at the European Council in June 2019 did not consider the findings of the political groups, which led the retiring Jean Claude Juncker to conclude that he was 
apparently the first and last Spitzenkandidat and that the mechanism itself would not become a new tradition as predicted.

The behavior of the European Council shows clearly that the Spitzenkandidaten procedure was not considered as a viable solution and indicates a lack of interinstitutional solidarity. The democratizing influence, which was the main aim from the EP's point of view, was not seen in the same way by the European Council, which was not interested in empowering the EP at the expense of its own competences.

The mechanism proposed in 2014 has not gained institutional sustainability in the EU system. However, the Spitzenkandidaten story can be considered to be part of cycle of institutional conflict in the EU. Its implementation (if continued) will become a gateway to circumvent the Treaty restriction preventing the EP from formally proposing a candidate for the post of Head of the Commission. Shifting the burden of responsibility to the factions offers an opportunity to ensure the democratic legitimacy of the European citizen's vote to its candidate, thus creating normative pressure on European governments to nominate the elected candidate. Ultimately, if the normative power was not sufficient, the EP could threaten to block any alternative candidate proposed by the governments (Schimmelfennig, 2014).

The first question that arises in the context of assessing the system of lead candidates is whether we are faced with yet another theoretical, ill-conceived, self-limiting solution? The Spitzenkandidaten process was based on the idea of automatism - a political group would designate a candidate to hold one of the most important positions in the EU, which will convince European citizens to vote for the group and will raise overall awareness among Europeans about the essence of the elections themselves. This would increase citizens' sense of agency and convince them that it is their voices that determine the appointment of the key position in the European Union's institutional system. At the same time, it would strengthen the "democratic legitimacy" of EU institutions, which is poorly perceived by citizens, and justify future electoral participation (Niklewicz, 2014, p. 3). But how can such an effect be expected, with a preliminary assumption that the success of the procedure is determined by high voter turnout? This leads to a paradoxical situation in which the result and conditionality are perceived in the same way.

Continuing this line of analysis, it can be assumed that the democratic influence of the Spitzenkandidaten mechanism will only occur if there is a high turnout and a truly European electoral campaign that raises issues of European origin instead of using it as a forum for national 
ideological struggles. Perhaps the first step would be to create transnational electoral lists. Meanwhile, only $5 \%$ of voters admitted that their motivation to participate in the EP elections was connected with influencing the election of the head of the Commission ${ }^{24}$. Additionally, the unfinished campaign and the rush to prepare the procedure itself makes it possible to see the issue from the systemic perspective, and not from the point of view of individual failures. (Russack, 2018, p. 2).

The approach of the institutions involved in the election of the President was also important, and from the political point of view, they could lose or gain as a result of the new procedure. The state as of 2019 clearly shows that the European Council distances itself from the new way of electing the head of the Commission. The lack of support for the lead candidates and the choice of an unknown, previously not considered, candidate - Ursula van Dr Leyen - was a clear signal from the heads of state that they do not intend to submit to the system imposed in 2014, which diminishes the role of the body that gives political impetus to the integration process. Studies explaining the phenomenon of the mechanism introduced in 2014 often include the word "forced" (Russack; 2018, p. 1), to describe the European Council's approach to the fulfilment of the new rules of the game. One might argue that this is a continuation of the trend in interinstitutional relations which has led to the development of the principle of interinstitutional balance, which clearly shows the European Parliament's ongoing struggle with the intergovernmental institutions.

In May 2019, the system did not work as planned and turned out to be another project involving not citizens but political elites, which put a stop to the expected democratizing effect. So, has the fight that the European Parliament been waging for a long time to establish a parliamentary system been lost?

The solution was conceived as a path towards strengthening the transparency and legitimacy of elections, but it has resulted in an increased level of politicization of interinstitutional cooperation. One can therefore be disappointed that the mechanism, which by its very nature was intended to replace the back-door introduction of candidates for President of the Commission with a more transparent nomination mechanism, has in effect failed, and the interinstitutional dispute on this issue has been perceived by Eurosceptics as ,,another weakness of the EU”.

\footnotetext{
${ }^{24} \mathrm{http}: / /$ www.europarl.europa.eu/pdf/eurobarometre/2014/post/post_2014_survey_analitical_overview_en.pdf
} 
It seems that what may accompany the attempts to conclude on the application of the Spitzenkandidaten mechanism is the question of whether this system could be saved and made an acceptable method for all? The solution is likely to lie in a more flexible approach which will take into account both the need to strengthen the parliamentary nature of the political game in the EU and the strong intergovernmental trends within the European Council. The whole agreement should be based on transparency, interinstitutional respect and the creation of a relationship that is leaves one satisfied, not disregarded.

Like Stergios Fotopoulos noticed, the Spitzenkandidat process had a strong impact on the political and institutional landscape of the EU, while increasing the visibility of the election of the Commission president for European citizens. Yet, in 2019 the process was discarded. This was a step backwards, in the direction of a less transparent and less inclusive decision-making process made behind closed doors, and the inter-institutional quarrel over the issue was perceived by some Eurosceptics as 'another EU weakness' (Fotopoulos, 2019, s. 200).

So, what are the recommendations? Above all, when seeking procedures for an inclusive system comparable to parliamentary rules, the fundamental principles on which political competition in the parliamentary system is based must be adhered to. In the context of European integration, this should imply strong support for the candidate of a political group in appointing the lead candidate. Meanwhile, Weber's candidacy was not strongly supported by the European MPs, and the election results were worse than in 2014 (182 seats for the EPP in 2019 compared to 221 in 2014). From the perspective of the European Council, it weakened its legitimacy and confirmed the wrong approach to the appointment of the head of the European Commission. The effective functioning of the mechanism would require real trust between the institutions, in particular the European Council and the European Parliament. That way, the procedure for selecting the head of the EC would become less similar to a tender. In effect, it would be an expression of effective cooperation between institutions representing two different interests in the process of European integration, and a symbol understanding that the real winners in the process should be the citizens and not any of the institutions.

Perhaps the solution would also be, as Cristian Ghinea suggests, to select several candidates from within the political group. Each one of them would then start their own campaign, which would reinforce the Europeanness of the elections. However, this would require a number of additional steps, such as the already suggested introduction of transnational EP electoral lists, 
which would exist alongside national lists. It would also be necessary to sign a binding agreement between the EP and the European Council which would prevent the latter from withdrawing from the agreements (Ghinea, 2019) ${ }^{25}$.

As Russack points out, efforts to improve the integration system are justified, but expectations need to be managed skillfully. The EU's capabilities are restricted. In reality, most reform ideas are linked to decisions made by national governments or national parties. Their role as a facilitator of change is essential to achieve a serious and long-lasting reach.

Considering the above observations in the context the implementation of the lead candidate system, one might argue that the above assumptions were not fulfilled. From the beginning, the mechanism was based on political pressure (from the Commission and the European Parliament) and not on the will of the Member States. How could one therefore expect to support this system and promote it among citizens if it was not supported by member state leaders themselves? (Russack; 2018, p.3).

Whatever the conclusions, we can certainly assume that the 2019 election showed a pragmatic approach to the Spitzenkandidaten mechanism. Protecting own prerogatives was victorious, and the impact of transnational cooperation was confirmed. The transnational institutions elude intergovernmental control, and state institutions aim to maintain their authority over the transnational ones.

Therefore, does the mechanism have a democratizing impact on the EU political system? Its more prominent pragmatic aspect, intertwined with the interinstitutional game of empowerment of the European institutions, seems to be more evident. When confronted with the pattern presented at the beginning, which consisted in the inability to simultaneously achieve the effect of democracy, deepened integration and preservation of sovereignty, it is evident that the drive to democratize the process of European integration gave in to state influence. One might see it as intergovernmental factors restoring European integration in a pragmatic way, instead of building an idealistic, parliamentary image, similar to that of a state.

\footnotetext{
${ }^{25}$ Another solution might be to assume that candidates should resign from holding multiple high ranked positions during the campaign. This would make their efforts credible and, at the same time, make the opportunities during the campaign equal for all.
} 
Acknowledgements: Publication financed as part of the Polish Minister of Science and Higher Education program called "Dialogue "in the years 2019-2021.

\section{References}

1. Azmanova, A., 2017. The Crisis of ,the Crisis of Europe, in: A. Amin, P .Lewis (eds.), European Union and disunion. Reflections on European identity, London.

2. Baldoli R., Gänzle S., Shackleton M., 2014. Overthrowing Secrecy. The Spitzenkandidaten experiment and a new chance for a European party system, CEPS Commentary, 4 August 2014; http://aei.pitt.edu/53004/1/Overthrowing_Secrecy _Spitzenkandidaten_Experiment.pdf (accessed 27 February 2020).

3. Barcz J., 2017. Ustrój lizbońskiej Unii Europejskiej. Podstawy traktatowe, struktura, instytucje $\quad \mathrm{i}$ prawo, Wszechnica IJM Piaseczno; https://repozytorium.kozminski.edu.pl/system/files/Barcz_Ustr\%C3\%B3j\%20lizbo\% C5\%84skiej\%20Unii.pdf (accessed 27 February 2020)

4. Blondel, J., Sinnott R., Svensson, P., 1998. People and Parliament in the European Union : Participation, Democracy, and Legitimacy, Oxford: Clarendon Press.

5. Borkowski P., 2019. Unia Europejska - Próba Przedolimpijska Rocznik Strategiczny $2018 / 2019$.

6. Christiansen, T., 2016. After the Spitzenkandidaten: fundamental change in the EU's political system? West European Politics, vol. 39(5), pp. 992-1010.

7. Crombez, C., Hix, S., 2011. Treaty reform and the Commission's appointment and policy-making role in the European Union. European Union Politics, vol. 12(3), pp. 291-314.

8. Crum, B., Fossum, J.E., 2009. The Multilevel Parliamentary Field: a framework for theorizing representative democracy in the EU. European Political Science Review, vol.2(1), pp $249-271$.

9. Czapiński J., Panek, T., 2015. Social diagnosis 2015. Objective and subjective quality of life in Poland, Contemporary Economics, vol. 9(4), pp. 325-366.

10. De Wilde, P. 2020, The Fall of the Spitzenkandidaten: Political Parties and Conflict in the 2019 European Elections', in Kritzinger, S., C. Plescia, K. Raube, J. Wilhelm and 
J. Wouters (Eds), Assessing the 2019 European Parliament Elections, Abingdon: Routledge, Ch. 3, pp. 37-53

11. Déloye, Y., M., 2007. Encyclopedia of European Elections, Basingstoke: Palgrave Macmillan.

12. Dinan, D., 2016. Governance and Institutions: A More Political Commission. Journal of Common Market Studies, vol. 54, pp. 101-116.

13. Estrada M., A., R., 2014. Economic Waves: The Effect of the U.S. Economy on the World Economy, Contemporary Economics, vol. 8(3), pp. 247-256.

14. Euractiv, 2019 Macron: 'No Majority for Mr. Weber' and Other Spitzenkandidats. Euractiv, 21 June.

15. Eurobarometer (2014), 2014 post-election survey EUROPEAN ELECTIONS 2014 ANALYTICAL OVERVIEW, Directorate-General for Communication PUBLIC OPINION MONITORING UNIT, Brussels, October 2014, http://www.europarl.europa.eu/pdf/eurobarometre/2014/post/post_2014_survey_anali tical_overview_en.pdf (accessed May 2019).

16. European Commission (2013) Commission Recommendation of 12 March 2013 on enhancing the democratic and efficient conduct of the elections to the European Parliament (2013/142/EU). Available at: http://eur-lex.europa.eu/legalcontent/EN/TXT/?uri=uriserv:OJ.L_.2013.079.01.0029.01.ENG $\quad$ (accessed 27 February 2020).

17. European Commission, 12 September 2012, 'State of the Union 2012 Address', https://ec.europa.eu/soteu2012/ (accessed 27 February 2020)

18. European Parliament (2012) European Parliament Resolution of 22 November 2012 on the, elections to the European Parliament in 2014 (2012/2829(RSP)), http://www.europarl.europa.eu/sides/getDoc.do?type $=$ TA\&language $=$ EN\&reference $=$ P7-TA-2012-462 (accessed 27 February 2020).

19. European Parliament, 2019a Debate of the candidates for the presidency of the Commission. Video, European Parliament, Brussels, 15 May.

20. European Parliament, 2019b Conference of Presidents' Statement. Press Release, European Parliament, Brussels, 28 May. 
21. Ezzat A., M., Fayed M., E., 2020, Central Bank Independence and Democracy: Does Transparency Matter?, Contemporary Economics, vol. 14(2), pp. 90-111.

22. Follesdal, A., Hix, S., 2006. Why there is a democratic deficit in the EU: A response to Majone and Moravcsik, Journal of Common Market Studies, vol. 44(3), pp. 533-562.

23. Fotopoulos S., 2019. What sort of changes did the Spitzenkandidat process bring to the quality of the EU's democracy? European View, vol. 18(2), pp. 194-202.

24. Fox, B., The Spitzenkandidaten - this time was it different, „EUobserver”, 26 of May 2014, http://euobserver.com/news/124235 (accessed 28 February 2020).

25. Franklin, M., N., Hobolt, S., B., 2011. The legacy of lethargy: How elections to the European Parliament depress turnout, Electoral Studies, vol. 30(1), pp. 67-76.

26. Grosse, T., 2013 (ed.), Między polityką a rynkiem. Kryzys Unii Europejskiej w analizie ekonomistów i politologów, Warszawa.

27. Haberams, J., 2015. Democracy in Europe: Why the Development of the EU into a Transnational Democracy Is Necessary and How It Is Possible, European Law Journal, vol. 21(4), pp. 546-557.

28. Held, D., 1987. Models of democracy, Stanford.

29. Held, D., 1993. Democracy and the New International Order, London

30. Held, D., Koehler, M., eds., 1998. Re-imagining Political Democracy - Studies in Cosmopolitan Democracy, Cambridge.

31. Hix, S., 1997. Executive selection in the European Union: Does the commission president investiture procedure reduce the democratic deficit?, European Integration Online Papers, 1(21), pp 1-15; http://eiop.or.at/eiop/pdf/1997-021.pdf (accessed 27 February 2020).

32. Hix, S., Noury, A., G., Roland, G., 2007. Democratic Politics in the European Parliament, Cambridge University Press.

33. Hobolt, S., B., 2014. A vote for the President? The role of Spitzenkandidaten in the 2014 European Parliament elections, Journal of European Public Policy, vol. 21(10), pp. $1528-1540$.

34. Hobolt, S., B., Spoon, J., Tilley J., 2009. A vote against Europe? Explaining defection at the 1999 and 2004 European parliament elections, British Journal of Political Science, vol. 39(1), pp. 93-115. 
35. Juncker, J-C., 2014. A New Start for Europe: My Agenda for Jobs, Growth, Fairness and Democratic Change, Political Guidelines for the Next European Commission and Opening Statement in the European Parliament Plenary Session, 37.

36. Kassim, H., 2016. What's new? a first appraisal of the Juncker Commission, European Political Science, vol.16, pp. 1-20.

37. Kosowska-Gąstoł, B., 2019. Entuzjaści versus sceptycy - układ sił politycznych w Parlamencie Europejskim VIII kadencji oraz powyborcze scenariusze rozwoju [2019 Enthusiasts versus sceptics - the composition of political forces in the European Parliament for the 8th parliamentary term and post-election development scenarios], in: A. Nitszke, J. Węc (eds.), Podsumowanie VIII kadencji Parlamentu Europejskiego. Wyzwania integracji europejskiej $\mathrm{w}$ latach 2014-2019 [Summary of the eighth parliamentary term. The challenges of European integration in 2014-2019], Kraków. Tilindyte, L., 2019. Election of the President of the European Commission. Understanding the Spitzenkandidaten process, EPRS | European Parliamentary Research Service, PE 630.264 - April 2019.

38. Mahony, H., 2015. The Spitzenkandidaten Coup, EUobserver 4 January 2015, https://euobserver.com/review-2014/126456; (access 23.02.2020).

39. Milward, A., 1992. The European Rescue of the Nation - State, Berkley, CA: University of California Press.

40. Niklewicz, K., 2014. Sposób na wyborcę [Approaching voters], Instytut Obywatelski. Analiza $\mathrm{nr} 4$.

41. Nowak-Far, A., 2012. Unia Europejska jako czynnik demokracji [The European Union as a factor in democracy], in: K.A. Wojtaszczyk, J. Szymańska (eds..), Deficyt demokracji w Unii Europejskiej [Democratic deficit in the EU], Warszawa.

42. Nugent, N.,, Rhinard, M., 2019. The 'political' roles of the European Commission, Journal of European Integration, vol. 41(2), pp. 203-220.

43. Oddovar, E., Fossum, J., E., eds. 2012. Rethinking Democracy and the European Union, Routledge.

44. Open Europe 2014. Does Jean-Claude Juncker have a "popular mandate" to become the next President of the European Commission? Press Release, 12 June. Available at: http://www.openeurope.org.uk/Article/Page/en/LIVE?id=20223\&page=PressReleases 
45. Peñalver, N., G., Priestley, J., 2015. The Making of a European President, Palgrave Macmillan.

46. Pop, V., 2014. Buses, selfies, posters: EU campaign in full swing, "EU observer" http://euobserver.com/eu-elections/124152 (accessed 27 February 2020)

47. Radaelli, C., 1999. Technocracy in the European Union, London: Routledge.

48. Reif, K., Schmitt, H., 1980. Nine second-order national elections. A conceptual framework for the analysis of European election results, European Journal for Political Research, vol. 8, pp. 3-44.

49. Renda, A., Laurer M., Modzelewska A. and Zarra A. (2019) Feasibility Study: Introducing "One-In-One-Out" in the European Commission, Final Report for the German Ministry for Economic Affairs and Energy, CPES, 05.12.2019, https://www.ceps.eu/ceps-publications/feasibilitystudy-introducing-one-in-one-out-in-the-european-commission/ (accessed May 2019).

50. Rezolucja z 22 listopada 2012 r w wyborach do PE w 2014 r. 2012/2829(RSP) https://eur-lex.europa.eu/legal-content/PL/TXT/?uri=CELEX\%3A52012IP0462

51. Rittberger, B., 2005. Building Europe's Parliament. Democratic Representation beyond the Nation State, Oxford University Press, Oxford.

52. Rodrik, D., 2005. Has Globalization Gone Too Far?, Washington, DC Inst. for International Economics

53. Rodrik, D., 2011. The Globalization Paradox, Oxford: Oxford University Press.

54. Russack, S., 2019. Institutional Rebalancing: the 'Political' Commission, https://www.ceps.eu/ceps-publications/institutional-rebalancing-politicalcommission/ (accessed 28 February 2020).

55. Russack, S., The problem with the Spitzenkandidaten system, Commentary. Thinking Ahead Europe, https://www.ceps.eu/ceps-publications/problem-spitzenkandidatensystem/ (accessed 27 February 2020).

56. Sartori, G., 1998. Teoria demokracji [Theory of democracy], Warszawa.

57. Schimmelfennig, F., 2014. The Spitzenkandidaten plot: The European Parliament as a strategic competence-maximizer. Europedebate.ie.: http://europedebate.ie/spitzenkandidaten-plot-european-parliament-strategiccompetence-maximizer/ (accessed 23 Fabruary 2020). 
58. Schulz-Forberg, H., Stråth, B., 2012. The Political History of European Integration: The Hypocrisy of Democracy-Through-Market, Routledge.

59. The Spitzenkandidaten procedure. Genesis and nemesis of a constitutional convention? https://njb.nl/Uploads/2015/9/LLM-Thesis---LLM-European-Law---Paul-W.-Post.pdf (accessed 20 February 2020).

60. Tilindyte, L., 2019, Election of the President of the European Commission Understanding the Spitzenkandidaten process, European Parliamentary Research $\begin{array}{llllll}\text { Service, } & \text { PE } & 630.264 & - & \text { April 2019; }\end{array}$ http://www.europarl.europa.eu/RegData/etudes/BRIE/2018/630264/EPRS_BRI(2018 630264_EN.pdf (accessed 27 February 2020).

61. Tömmel, I., 2020. Political leadership in times of crisis: the Commission presidency of Jean-Claude Juncker, West European Politics, vol. 43(5).

62. TRAKTAT Z NICEI ZMIENIAJĄCY TRAKTAT O UNII EUROPEJSKIEJ, TRAKTATY USTANAWIAJĄCE WSPÓLNOTY EUROPEJSKIE I NIEKTÓRE ZWIĄZANE Z NIMI AKTY, Dz. Urz. WE 2001 C 80, s. 1, Akty podstawowe prawa Unii Europejskiej, Dziennik Ustaw, Załącznik nr 2 do nru 90, 30.04.2004, poz. 864, T. II, s. 660 http://oide.sejm.gov.pl/oide/images/files/dokumenty/traktaty/Traktat_z_Nicei_PL_1.p df (accessed May 2019).

63. Treib, O., 2014. The Voter Says No, but Nobody Listens. Causes and Consequences of the Eurosceptic Vote in the 2014 European Elections, Journal of European Public Policy, vol. 21(10).

64. van der Eijk, C., Franklin, M., N., 1996. Choosing Europe? the European Electorate and National Politics in the Face of Union, Ann Arbor: University of Michigan Press.

65. Wersje skonsolidowane Traktatu o Unii Europejskiej i Traktatu o funkcjonowaniu Unii Europejskiej, Dziennik Urzędowy UE [Consolidated versions of the Treaty on European Union and the Treaty on the Functioning of the European Union, Official Journal of the EU] (2016/c 202/01).

66. Westlake, M., (2016), Chronicle of an election foretold: the longer-term trends leading to the 'Spitzenkandidaten' procedure and the election of Jean-Claude Juncker as European Commission President, LEQS paper No. 102/2016; 
http://www.lse.ac.uk/europeanInstitute/LEQS\%20Discussion\%20Paper\%20Series/LE QSPaper102.pdf (accessed 27 February 2020).

67. Westlake, M., 2016. Chronicle of an election foretold: the longer-term trends leading to the 'Spitzenkandidaten' procedure and the election of Jean-Claude Juncker as European Commission President', LEQS paper No. 102/2016.

68. Wierzchowska, A., 2013., Democratic governance in supranational space, Studia Politologiczne, vol. 27.

69. Wille, A., 2012. The politicization of the EU Commission: democratic control and the dynamics of executive selection, International Review of Administrative Sciences, vol. 78(3), pp. 383-402.

70. Wojtaszczyk, K., A., Czy w Unii Europejskiej istnieje demokratyczny deficyt?[Is the EU suffering from democratic deficit] (2012), in: K.A. Wojtaszczyk, J. Szymańska, eds., Deficyt demokracji w Unii Europejskiej [Democratic deficit in the EU], Warszawa. 